\title{
Changes in height growth patterns in the upper tree-line forests of Tierra del Fuego in relation to climate change
}

\author{
Cambios en los patrones de crecimiento de los bosques del límite superior altitudinal de \\ Tierra del Fuego en relación al cambio climático
}

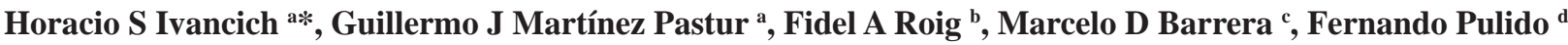 \\ *Corresponding author: ${ }^{a}$ Centro Austral de Investigaciones Científicas (CADIC-CONICET), \\ Bernardo Houssay 200, Ushuaia, Tierra del Fuego, Argentina, horacioivancich@yahoo.com.ar \\ b Instituto Argentino de Nivología, Glaciología y Ciencias Ambientales (IANIGLA-CONICET), Mendoza, Argentina. \\ ${ }^{c}$ Universidad Nacional de La Plata, LISEA, Facultad de Ciencias Agrarias y Forestales, La Plata, Argentina. \\ ${ }^{\mathrm{d}}$ Universidad de Extremadura, Spain.
}

\begin{abstract}
SUMMARY
Nothofagus pumilio occupy the mountain slopes reaching to the upper altitudinal limit of the forests. This extremely stressful environment represents the optimum conditions to study changes in growth patterns due to climate variations. Our goal was to analyze recent changes in stem height growth in forests located in the upper altitudinal tree-line along Tierra del Fuego (Argentina), and establish possible linkages to changes observed in surface temperature during the last decades. Nine locations were sampled, and four plots were measured in each location. Forest structure was characterized, and stem analyses were performed to assess height growth patterns. ANOVAs and classification analyses were conducted using location and time as main variables. Tree-growth height increased with time, e.g. 1.0 cm.year ${ }^{-1}$ during 1870-1959, 2.7 cm year $^{-1}$ during 1960-1979, and $5.0 \mathrm{~cm}_{\text {year }}{ }^{-1}$ during 1980-2010. These differences were significant between periods and locations, and can be related to its geographical situation. Increment in stem height growth seems to be related with the worldwide surface air temperature. A decline in stem height growth registered during the last two decades can also be related with the regional decrease in the mean air temperature. The analysis of stem height growth is a useful tool to evaluate the incidence of climate change over trees growing under extreme environmental conditions.
\end{abstract}

Key words: tree-line, Nothofagus, height growth, climate change, forest structure.

\section{RESUMEN}

Los bosques de Nothofagus pumilio ocupan las laderas de montaña hasta alcanzar el limite altitudinal del bosque. Estos ambientes extremos, donde los bosques están bajo condiciones de estrés ambiental, son óptimos para estudiar patrones de cambio debidos a variaciones climáticas. El objetivo fue analizar cambios recientes en el crecimiento en altura en bosques localizados en el tree-line altitudinal en Tierra del Fuego (Argentina) y establecer posibles vinculaciones con cambios en la temperatura observados durante las últimas décadas. Se muestrearon nueve sitios, y se midieron cuatro parcelas en cada sitio. Se determinó la estructura forestal y se realizaron análisis fustales para evaluar los patrones de crecimiento en altura. Se realizaron ANOVA y análisis de clasificación usando como factores principales al sitio y al tiempo. El crecimiento en altura aumentó a lo largo del tiempo, e.g. 1,0 cm año-1 durante 1870-1959, 2,7 cm año ${ }^{-1}$ durante 1960-1979 y 5,0 cm año ${ }^{-1}$ durante 1980-2010. Esas diferencias fueron significativas entre períodos de tiempo y sitios, pudiendo estar relacionadas con la localización geográfica. El incremento en el crecimiento en altura observado está relacionado con los cambios en la temperatura de superficie experimentada en todo el mundo. Una declinación en el crecimiento en altura durante las últimas dos décadas, también puede estar relacionada con una disminución regional de la temperatura de aire. El análisis del crecimiento en altura es una herramienta de utilidad para evaluar la incidencia que tiene el cambio climático sobre el crecimiento de los árboles que crecen en ambientes extremos.

Palabras clave: bosque altitudinal, Nothofagus, crecimiento en altura, cambio climático, estructura forestal.

\section{INTRODUCTION}

Lenga (Nothofagus pumilio (Poepp. et Endl.) Krasser) is an endemic species of Patagonian forests with a wide geographical distribution ( $35^{\circ} 35^{\prime}$ to $55^{\circ} 31^{\prime}$ S). These forests live from the sea level (up to $30 \mathrm{~m}$ height) to the upper altitudinal tree-line, where forming forests with a stun- ted morphology of 1-2 m high. Sometimes, it is possible to find ñirre (Nothofagus antarctica (Forster) Oersted) and guindo (Nothofagus betuloides Bidr. Egefam) in the treeline. Similar to that occurs in these forests, in mountain regions of Northern Hemisphere and Australasia, morphological changes induced by thermal variations in altitudinal gradients were observed (Kullman 1979, Holtmeier 2000). 
In these environmental conditions, the forests growth under the extreme stress conditions, mainly influenced by thermal variations (Tuhkanen 1992). In Tierra del Fuego, the correlation between growth and temperature increase with altitude, evidencing the greater influence of climate close to the tree-line (Massaccesi et al. 2008). Therefore, it is expected that these thermal changes should influence over growth rates, stem morphology and regeneration at the tree-line (Fajardo and McIntire 2012), being these environments the best places to study climate change processes (Cuevas 2000, Daniels 2000).

The goal of this study was analyze recent changes in height growth patterns in the upper tree-line N. pumilio forests along Tierra del Fuego (Argentina), and establish possible linkages to changes observed in surface temperature.

\section{METHODS}

Nine locations were selected in the central-south sector of Tierra del Fuego (Argentina), covering ranges of latitude, longitude and aspects of tree-line forests (table 1). In each location, a tree-line area without evident recent disturbances was chosen for samplings. Four plots of $50 \mathrm{~m}^{2}$ each were established, and basal diameter was measured in all trees. In each plot, a dominant tree was chosen and cross sections cuts were obtained every $25 \mathrm{~cm}$ from the base to the total height. Cross sections were used for stem analysis to reconstruct the history of height growth in each tree. Height growth increments were compared with worldwide surface air temperature (Jones et al. 1999) for the period 1900-1999, and local air temperature of weather stations for the period 2000-2010.

A factorial ANOVA was performed to analyze height growth patterns using location and time (1870-1959, 19601979 and 1980-2010) as main factors. Comparisons of means were performed using Tukey test at $P>0.05$. Furthermore, a cluster analyses was conducted using the Ward's method linkage with Euclidean distance matrix to find si- milarities among the different locations and height growth increments of each decade for the period 1910 to 2010.

\section{RESULTS}

Sampling locations covered a north-south gradient from $54^{\circ} 52^{\prime} 29^{\prime \prime}$ to $54^{\circ} 31^{\prime} 42^{\prime \prime} \mathrm{S}$, and east-west gradient from $66^{\circ} 40^{\prime} 32^{\prime \prime}$ to $68^{\circ} 18^{\prime} 03^{\prime}$ ' W, with different aspects, and reaching altitudes from 518 to $662 \mathrm{~m}$ a.s.l. (table 1). Sampled forests have ages from 67 to 140 years, with basal diameters between 6.6 and $16.7 \mathrm{~cm}$, dominant heights between 1.7 and $3.0 \mathrm{~m}$, densities between 3,850 and 6,250 trees ha-1 ${ }^{-1}$ and basal area at stem base between 26.3 and $86.3 \mathrm{~m}^{2}$ ha $^{-1}$ (table 1).

In the factorial ANOVA, height growth increment significantly varied among locations, as well as the time period (table 2). Fagnano location presented the lowest height growth increment $\left(1.6 \mathrm{~cm}_{\text {year }}{ }^{-1}\right)$, and was significantly different from Escondido, Malvinera, Observación and Tristen locations (2.7 to $3.8 \mathrm{~cm}_{\text {year }}^{-1}$ ). The remaining locations showed intermediate values between these groups. Significant differences were found among time periods. Height growth increments gradually increased along the time, reaching to $1.0 \mathrm{~cm}^{\text {year }}{ }^{-1}$ during 1870-1959, $2.7 \mathrm{~cm}$ year $^{-1}$ during 1960-1979, and $5.0 \mathrm{~cm}$ year ${ }^{-1}$ during 1980-2010. Significant interactions were detected due to the height growth increments differed in magnitudes among period for the different locations (figure 1). A similar pattern of height growth increment was observed for all sites, related to the time period. Increments of height growth were higher during 1980-2010 period compared to 1960-1979, and were higher during 1960-1979 compared to $1870-1959$ period.

In the cluster analysis, it was observed two groups at Euclidean linkage distance of 8 defined by the distance to major water bodies (Fagnano Lake, Beagle Channel or Argentinean sea). One group composed of three locations (Malvinera, Tristen and Observación) presented distances

Table 1. Geographic situation of sampling sites and mean values of forest structure variables registered in each site.

Situación geográfica de los sitios de muestreo y valores medios de las variables de estructura forestal registradas en cada sitio.

\begin{tabular}{|c|c|c|c|c|c|c|c|c|c|}
\hline \multirow[t]{2}{*}{ Location } & \multirow[t]{2}{*}{ Latitude } & \multirow[t]{2}{*}{ Longitude } & \multirow[t]{2}{*}{ Aspect } & \multirow{2}{*}{$\begin{array}{l}\text { Altitude } \\
\text { (m a.s.l.) }\end{array}$} & \multirow{2}{*}{$\begin{array}{c}\text { Age } \\
\text { (years) }\end{array}$} & \multirow{2}{*}{$\begin{array}{c}\mathrm{D} \\
(\mathrm{cm})\end{array}$} & \multirow{2}{*}{$\begin{array}{c}\mathrm{H} \\
(\mathrm{m})\end{array}$} & \multirow{2}{*}{$\frac{\mathrm{N}}{\left(\text { trees ha }^{-1}\right)}$} & \multirow{2}{*}{$\frac{\text { BA }}{\left(\mathrm{m}^{2} \mathrm{ha}^{-1}\right)}$} \\
\hline & & & & & & & & & \\
\hline A: Andorra & $54^{\circ} 44^{\prime} 23^{\prime \prime}$ & 68¹8’03”' & $\mathrm{E}$ & 662 & 67 & 9.2 & 2.1 & 6,000 & 46.3 \\
\hline B: Bronzovich & 543’'16”' & 67²8’08”' & $\mathrm{E}$ & 581 & 110 & 11.6 & 2.3 & 6,050 & 76.0 \\
\hline E: Escondido & 543’5” & $67^{\circ} 47^{\prime} 00^{\prime \prime}$ & W & 599 & 115 & 12.4 & 2.9 & 4,950 & 73.2 \\
\hline F: Fagnano & $54^{\circ} 31^{\prime} 42^{\prime \prime}$ & 6756’33” & $\mathrm{S}$ & 581 & 109 & 6.6 & 1.7 & 6,250 & 23.3 \\
\hline J: Jeujepen & $54^{\circ} 35^{\prime} 06^{\prime \prime}$ & $67^{\circ} 14^{\prime} 29^{\prime \prime}$ & $\mathrm{N}$ & 621 & 80 & 16.7 & 2.1 & 3,850 & 86.3 \\
\hline M: Malvinera & $54^{\circ} 37^{\prime} 23^{\prime \prime}$ & $66^{\circ} 40^{\prime} 32^{\prime \prime}$ & $\mathrm{N}$ & 545 & 114 & 11.1 & 3.0 & 5,400 & 54.3 \\
\hline N: Nontop & $54^{\circ} 52^{\prime} 29^{\prime \prime}$ & $67^{\circ} 09^{\prime} 41^{\prime}$ & $\mathrm{S}$ & 518 & 140 & 10.4 & 2.3 & 8,050 & 85.5 \\
\hline O: Observación & $54^{\circ} 36^{\prime} 56^{\prime \prime}$ & $67^{\circ} 05^{\prime} 44^{\prime \prime}$ & $\mathrm{W}$ & 606 & 79 & 9.5 & 3.0 & 4,088 & 29.9 \\
\hline T: Tristen & $54^{\circ} 42^{\prime} 44^{\prime \prime}$ & $67^{\circ} 56^{\prime} 47^{\prime \prime}$ & W & 610 & 85 & 8.1 & 2.8 & 5,250 & 36.0 \\
\hline
\end{tabular}

D: basal diameter; H: dominant height; N: density; BA: basal area at stem base. 
Table 2. Analysis of variance of height growth increment (HGI) considering location and time period as main factors.

Análisis de varianza del incremento del crecimiento en altura (HGI) considerando la localización y período de tiempo como factores.

\begin{tabular}{clc}
\hline Factor & \multicolumn{1}{c}{ Level } & HGI $\left(\mathrm{cm} \mathrm{year}^{-1}\right)$ \\
\hline & Fagnano & $1.61 \mathrm{a}$ \\
& Nontop & $1.65 \mathrm{ab}$ \\
& Bronzovich & $2.24 \mathrm{ab}$ \\
& Jeujepen & $2.61 \mathrm{ab}$ \\
& Escondido & $2.73 \mathrm{~b}$ \\
& Malvinera & $2.75 \mathrm{~b}$ \\
& Tristen & $3.13 \mathrm{~b}$ \\
& Andorra & $3.15 \mathrm{~b}$ \\
& Observación & $3.55 \mathrm{~b}$ \\
\cline { 2 - 3 } & \multicolumn{1}{c}{$\mathrm{F}$} & 4.52 \\
& \multicolumn{1}{c}{$P$} & $<.001$ \\
\hline \multirow{5}{*}{ Period } & $1870-1859$ & $1.00 \mathrm{a}$ \\
& $1960-1979$ & $2.67 \mathrm{~b}$ \\
& $1980-2010$ & $5.01 \mathrm{c}$ \\
\cline { 2 - 3 } Interactions & $\mathrm{F}$ & 208.19 \\
& $P$ & $<0.001$ \\
\hline \multirow{2}{*}{} & $\mathrm{F}$ & 6.37 \\
& $P$ & $<0.001$ \\
\hline
\end{tabular}

F: Fisher test; $P$ : probability level. Different letters denote significant differences between treatments by Tukey test $(P<0.05)$.

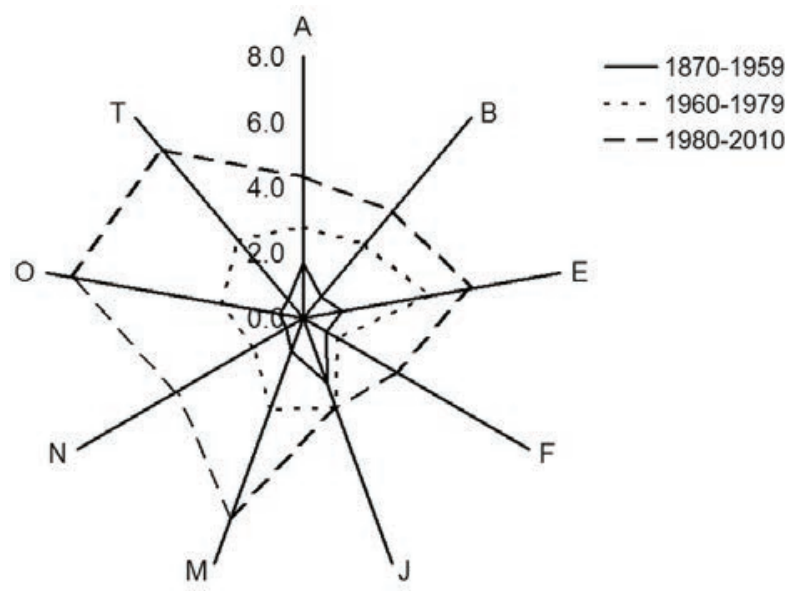

Figure 1. Height growth increments of each location at three period times used in table 2 . See location names in table 1. Incrementos del crecimiento en altura de cada localización en tres períodos de tiempo usados en el cuadro 2. Ver nombres de las localidades en el cuadro 1.

between 13.9 and $21.7 \mathrm{~km}$ with $\mathrm{N}$ and $\mathrm{W}$ aspects, while the second groups presented lower distances (1.3 to $9.4 \mathrm{~km}$ ). This last group presented two subgroups at euclidean linkage distance of five, one defined by $\mathrm{S}$ aspects (Fagnano and Nontop) and the second one by E (Andorra and Bronzovich), W (Escondido) and N (Jeujepen) aspects (figure 2).

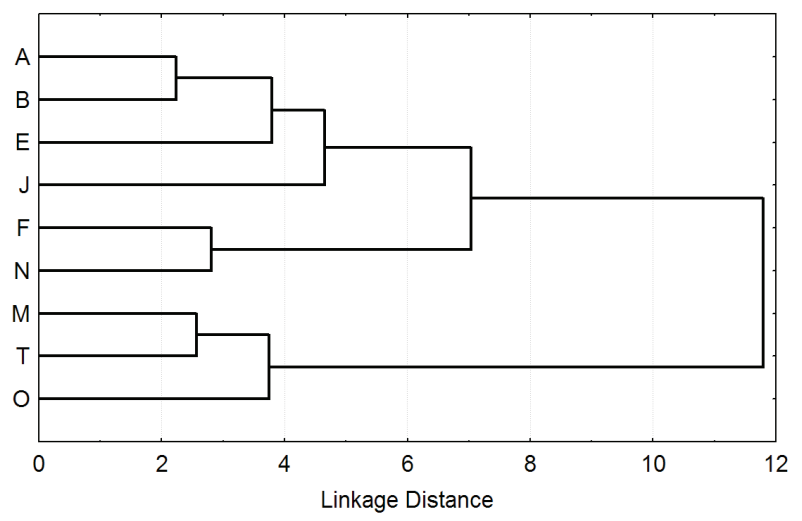

Figure 2. Cluster analysis of height growth increments of each decade (1910 to 2010) among locations. See location names in table 1 .

Análisis de agrupamiento de los incrementos del crecimiento en altura de cada década (1910 a 2010) entre localizaciones. Ver nombres de la localizaciones en el cuadro 1.

When average height growth increment for all location were compared with surface air temperature (figure 3), a correlation was observed: (a) a steady-state for the period before to 50's, (b) an increase in temperature and height growth increments between 60's and 80's, and (c) an slight decrease in temperature and height growth increments since the 90 's to the present (figure 3).

\section{DISCUSSION}

Forest structure variables registered in this work are comparable to those measured in other studies, e.g. Barrera et al. (2000) register in Tierra del Fuego values of 7,520 trees ha-1, basal area of $56 \mathrm{~m}^{2} \mathrm{ha}^{-1}, 10 \mathrm{~cm}$ diameter, $2 \mathrm{~m}$ height and ages of 137 years. Aspects and geographic locations (distance to major water bodies) influence more than forest structure and tree growth, e.g. south aspects produce lower increments, while greater distances to water bodies produce higher increment values.

The differences in height growth increments between 1960-1979 and 1870-1959, and between 1980-2010 and 1960-1979, are consistent with variations observed in the worldwide surface air temperature of the second half twentieth century (Jones et al. 2001). These changes are registered at different magnitudes along the worldwide forest ecosystems, but are more evident in forests growing at extreme environmental conditions (e.g. high latitudes or high elevations) (Massaccesi et al. 2008).

Height growth of the trees follow a typical sigmoid curve (Ivancich et al. 2011), defined by genetics of the species and the site quality of the stands (Klepac 1983). In our study, the changes in height growth pattern are not related to tree age. It was expected that greatest increments of growth occurred during the first years of development, and then decline gradually, reaching to values close to zero at 


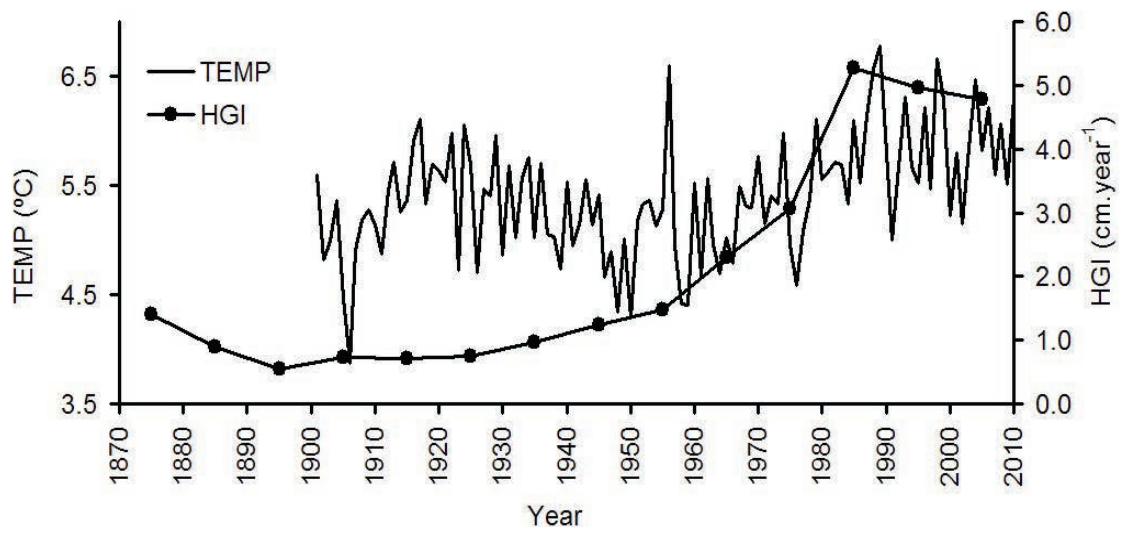

Figure 3. Surface air temperature (TEMP) in the studied area (1900-1999 were obtained from Jones et al. 1999, and 2000-2010 from local weather stations), and average height growth increment (HGI) for the nine studied locations.

Temperatura del aire superficial (TEMP) en el área de estudio (datos de 1900-1999 fueron obtenidos de Jones et al. 1999, y 2000-2010 de las estaciones climáticas locales) y el incremento promedio del crecimiento en altura (HGI) para las nueve localizaciones estudiadas.

the senescence stage (Martínez Pastur et al. 1997). However, the changes in height growth increments of this study are related to climate changes, with a trend to increase (e.g. 60 's to 80 's) or to decrease (90's to the present). This decrease in tree growth since the 80's is in agreement with other authors (e.g. Masiokas and Villalba 2004).

\section{CONCLUSIONS}

Stem analysis is a useful tool to evaluate the effects of climate change on trees growing under extreme environmental conditions. Forest structure and growth change according to aspects and geographic locations (distance to major water bodies), but increments in stem height growth seem to be correlated with worldwide surface air temperature. Tierra del Fuego forests growing at the altitudinal tree-line clearly increase height growth increments during the last 50 years, but also detect a decline during the last two decades correlated with the regional decrease in the average air temperature.

\section{REFERENCES}

Barrera MD, JL Frangi, LL Richter. 2000. Structural and functional changes in Nothofagus pumilio forests along an altitudinal gradient in Tierra del Fuego, Argentina. Journal of Vegetation Science 11: 179-188.

Cuevas J. 2000. Tree recruitment at the Nothofagus pumilio alpine timberline in Tierra del Fuego, Chile. Ecology 88: 840-855.

Daniels LD. 2000. The dynamics of altitudinal treelines in northern Patagonia: spatio-temporal influences of climate. Ph.D. Dissertation. Boulder, Colorado, USA. University of Colorado, Department of Geography
Fajardo A, EJB McIntire. 2012. Reversal of multicentury tree growth improvements and loss of synchrony at mountain tree lines point to changes in key drivers. Journal of Ecology 100: 782-794.

Holtmeier FK. 2000. Die Hoehengrenze der Gebirgswaelder. Carl Troll zum 100. Geburtstag - Bücher (Arbeiten aus dem Institut fuer Landschaftsoekologie). 337 p.

Ivancich H, G Martínez Pastur, PL Peri. 2011. Modelos forzados y no forzados para el cálculo del índice de sitio en bosques de Nothofagus antarctica en Patagonia Sur. Bosque 32(2): 135-145.

Jones PD, M New, DE Parker, S Martin, IG Rigor. 1999. Surface air temperature and its variations over the last 150 years. Reviews of Geophysics 37: 173-199.

Jones PD, TJ Osborn, KR Briffa. 2001. The evolution of climate over the last millennium. Science 292: 662-667.

Klepac D. 1983. Crecimiento e incremento de árboles y masas forestales. Segunda edición. Universidad Autónoma de Chapingo. Chapingo, México. 365 p.

Kullman L. 1979. Change and stability in the altitude of the birch tree-limit in the southern Swedish Scandes 1915-1975. Acta Phytogeographica Suecica 65: 1-121.

Martínez Pastur G, PL Peri, R Vukasovic, S Vaccaro, V Piriz Carrillo. 1997. Site index equation for Nothofagus pumilio Patagonian forest. Phyton 61(1/2): 55-60.

Masiokas M, R Villalba. 2004. Climatic significance of intra-annual bands in the wood of Nothofagus pumilio in southern Patagonia. Trees 18(6): 696-704.

Massaccesi G, FA Roig, GJ Martínez Pastur, MD Barrera. 2008. Growth patterns of Nothofagus pumilio trees along altitudinal gradients in Tierra del Fuego, Argentina. Trees 22(2): 245-255.

Tuhkanen S. 1992. The climate of Tierra del Fuego from a vegetation geographical point of view and its eco-climatic counterparts elsewhere. Acta Botanica Fennica 145: 1-64. 